THe Misfit of the family 


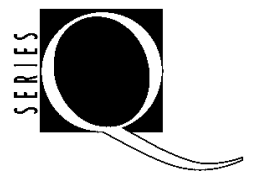

Edited by Michèle Aina Barale,

Jonathan Goldberg, Michael Moon,

and Eve Kosofsky Sedgwick 


\section{the Misfit of the family}

Balzac and the Social Forms of Sexuality Michael Lucey

DUKE UNIVERSITY PRESS DURHAM \& LONDON 2003 
(C) 2003 Duke University Press

All rights reserved

Printed in the United States

of America on acid-free paper @

Designed by Rebecca M. Giménez

Typeset in Carter and Cone Galliard

by Tseng Information Systems, Inc.

Library of Congress Cataloging-in-

Publication Data appear on the

last printed page of this book. 
para Lalo 
